\title{
IDENTIFICATION OF UTERIN MILK PROTEIN (UTMT) GENE IN BALI CATTLE USING DIRECT SEQUENCING
}

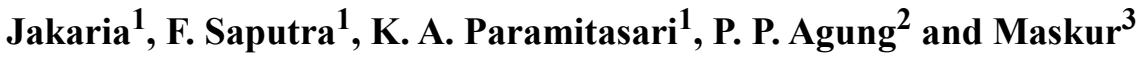 \\ ${ }^{1}$ Faculty of Animal Science, Bogor Agricultural University, \\ Jl. Agatis, Darmaga Campus, Bogor 16680 - Indonesia \\ ${ }^{2}$ Research Center for Biotechnology, Indonesian Institute of Science, \\ Jl. Raya Bogor KM 46, Cibinong 16911 - Indonesia \\ ${ }^{3}$ Faculty of Animal Science, Nataram University, \\ Jl. Majapahit No 62, Mataram 83125, Lombok - Indonesia \\ Corresponding E-mail: Jakaria_karman@yahoo.co.id
}

Received December 21, 2015; Accepted February 15, 2016

\begin{abstract}
ABSTRAK
Tujuan dari penelitian ini adalah untuk mengidentifikasi keragaman haplotipe fragmen gen UTMP ekson 5 pada sapi Bali menggunakan metode direct-sequencing. Sebanyak 60 sampel darah sapi Bali yang berasal dari BPTU sapi Bali di pulau Bali (20 ekor), BPTU Serading di pulau Sumbawa (20 ekor) dan Village Breeding Center (VBC) di Kabupaten Barru Sulawesi Selatan (20 ekor) digunakan untuk mengevaluasi keragaman genetik gen UTMP pada ekson 5. Data hasil sekuensing forward dan reverse dianalisis menggunakan Bioedit dan disejajarkan menggunkaan program MEGA5, sedangkan analisis haplotipe dilakukan menggunakan program DnaSPv5. Hasil dari sekuen fragmen gen UTMP ekson 5 menunjukkan ada 16 haplotipe dengan jumlah haplotipe terbesar ditemukan pada VBC Barru Sulawesi Selatan (8 haplotipe). Rataan keragaman haplotipe (h) dan nukleotida (p) tertinggi ditemukan di VBC Barru Sulawesi Selatan sebesar 0.7949 dan 0.0016. Selain itu, ditemukan juga insersi berupa minisatelit dengan susunan sekuen 5'-CCA GTC ATG AAG AAG GCA GAG GTC GTC GTG CCG GCG AAA-3'. Berdasarkan hasil yang diperoleh, variasi haplotipe dan minisatelit pada fragmen gen UTMP ekson 5 dapat dijadikan sebagai kandidat marka genetik spesifik sifat reproduksi pada sapi Bali dan strategi pemuliaannya di masa yang akan datang.
\end{abstract}

Kata kunci: gen UTMP, haplotipe, keragaman, sapi Bali

\begin{abstract}
The objective of this research was to identify diversity of exon 5 UTMP gene fragment in Bali cattle using direct sequencing. The total 60 blood samples of Bali Cattle derived from BPTU Bali in Bali siland (20 heads), BPTU Serading in Sumbawa island (20 heads) and Village Breeding Center in Barru District South Sulawesi (20 heads) were used to evaluate their genetic diversity at exon 5 UTMP gene. The forward and reverse data sequences were analyzed using Bioedit program and alignment analysis was carried out using MEGA5 program. Meanwhile haplotype analysis was performed by DnaSPv5 program. The result showed that partial sequences in exon 5 UTMP gene had 16 haplotypes with the highest number of haplotypes ware found in VBC Barru district South Sulawesi (8 haplotypes). Moreover, the highest average of haplotype (h) and nucleotide (p) diversity were found in VBC Barru district South Sulawesi were 0.7949 and 0.0016, respectively. In addition, minisatellite insersion was found in exon 5 UTMP gene fragment on Bali cattle which are consist of 5'-CCA GTC ATG AAG AAG
\end{abstract}


GCA GAG GTC GTC GTG CCG GCG AAA-3'. According to our results, haplotype and minisatellite variation in exon 5 UTMP gene fragment can be used as a candidate genetic marker specific for reproductive trait in the Bali cattle and for its strategy breeding program in the future.

Keywords: UTMP gene, diversity, haplotype, Bali cattle

\section{INTRODUCTION}

The uterine milk proteins (UTMP) gene known as serine proteinase inhibitor member of 14 (Serpina 14) (Kandasamy et al., 2010), is a protein secreted by the endometrial epithelium during pregnancy (Padua and Hansen, 2010). Serpina 14 (UTMP) gene has been further implicated as one of the important candidate genes for embryonic survival in the bovine (Khatib et al., 2007). Moreover Khatib el al., (2007) showed that UTMP gene expression found predominantly in reproductive tissues and play an important role in reproductive traits and it was located on chromosome 21, which consists of five exons (Ulbrich et al., 2009). It was further reported, the diversity of UTMP genes significantly affect fertilization and embryo survival rates in dairy cows (Khatib et al., 2009).

An Indonesia native animal genetic resources, Bali cattle has advantages in reproductive trait (Purwantara et al., 2012). It showed high reproductive capacity (high fertility and calf each year over a long time) (Entwistle and Lindsay 2003), higher reproductive efficiency than the cross-bred (Pribadi et al., 2015) and high conception rate in different regions (Australia, Malaysia, Bali and Timor) (McCool 1992). Until now, the information of the genetic characteristics of Bali cattle especially UTMP gene as a potential gene for reproductive traits were still limited. Based on many studied, it was already known that growth hormone receptor (GHR) gene (Zulkharnaim et al., 2010), growth hormone (GH) gene (Jakaria and Noor 2011), pituitary specific transcription factor-1 (Pit-1) gene (Jakaria and Noor 2015), calpastatin gene (CAST) (Putri et al., 2015) and prolactin (PRL) and signal transducers and activators of transcription 5A (STAT5A) genes (Paramitasari et al., 2015) had low genetic diversity using PCR-RFLP technique. Therefore, the aim of this study is to identify diversity based on haplotypes in exon 5 UTMP gene fragment in Bali cattle by direct sequencing technique. This study is important to designed the strategy of Bali cattle breeding program in the future.

\section{MATERIAL AND METHODE}

A total DNA sample of 60 blood samples of Bali cattle from BPTU Bali in Bali island (20 heads), BPTU Serading-Sumbawa NTB (20 heads) and Village Breeding Center (VBC) Barru South Sulawesi (20 heads) were extracted using DNA extraction kit (GeneAid protocol). Primer used to amplify the exon 5 UTMP gene fragment based Khatib et al., (2007) was 5'- GGC CCT TCA ACA AGC TGA GA -3' (forward) and 5'CTA GGG CTC TTG AAC GTT GA -3' (reverse) with length of PCR product 289 bp (Figure 1).

Amplification of exon 5 UTMP gene fragments used thermo cycler $\mathrm{AB}$ system machine added by PCR reagent $(50 \mu \mathrm{L})$ containing $10 \mu \mathrm{L}$ buffer $10 \mathrm{x}, 2 \mu \mathrm{L} \mathrm{MgCl}_{2}, 0.5 \mu \mathrm{L}$ of dNTP, $0.5 \mu \mathrm{L}$ of forward primer and $0.5 \mu \mathrm{L}$ of reverse primer, $0.2 \mu \mathrm{L}$ of Taq polymerase and distillated water $39.3 \mu \mathrm{L}$. PCR machine was performed with this following temperature condition: pre-denaturation at $95^{\circ} \mathrm{C}$ for $5 \mathrm{~min}, 35$ cycles (denaturation at $95^{\circ} \mathrm{C}$ for 10 seconds, annealing at $60^{\circ} \mathrm{C}$ for 20 seconds, and extension $72^{\circ} \mathrm{C}$ for 30 seconds), post extensions at $72^{\circ} \mathrm{C}$ for 5 minutes. PCR products were electrophoresed using $1.5 \%$ agarose gel contained EtBr. Furthermore, PCR products were sequenced using the machine sequencer (ABI Prims 3100-Avant Genetic Analyzer) in the $1^{\text {st }}$ Base sequencing company, Selangor, Malaysia. The forward and reverse of exon 5 UTMP gene fragment sequences were edited using Bioedit (Hall, 1999) and MEGA5 programs (Koichiro et al., 2011). Haplotype analysis was carried out by DnaSP v5 program (Librado and Rozas, 2009).

\section{RESULT AND DISCUSSTION}

\section{Amplification of Exon 5 UTMP Gene}

Optimum temperature of exon 5 UTMP gene fragment in Bali cattle was obtained at $60^{\circ} \mathrm{C}$ for 20 seconds. Figure 2 showed that the PCR products of exon 5 UTMP gene fragment in Bali cattle (405 bp) were different from the PCR product reference (289bp with Genbank access number L22095). PCR product of Bali cattle was longer than the one of reference because there was 


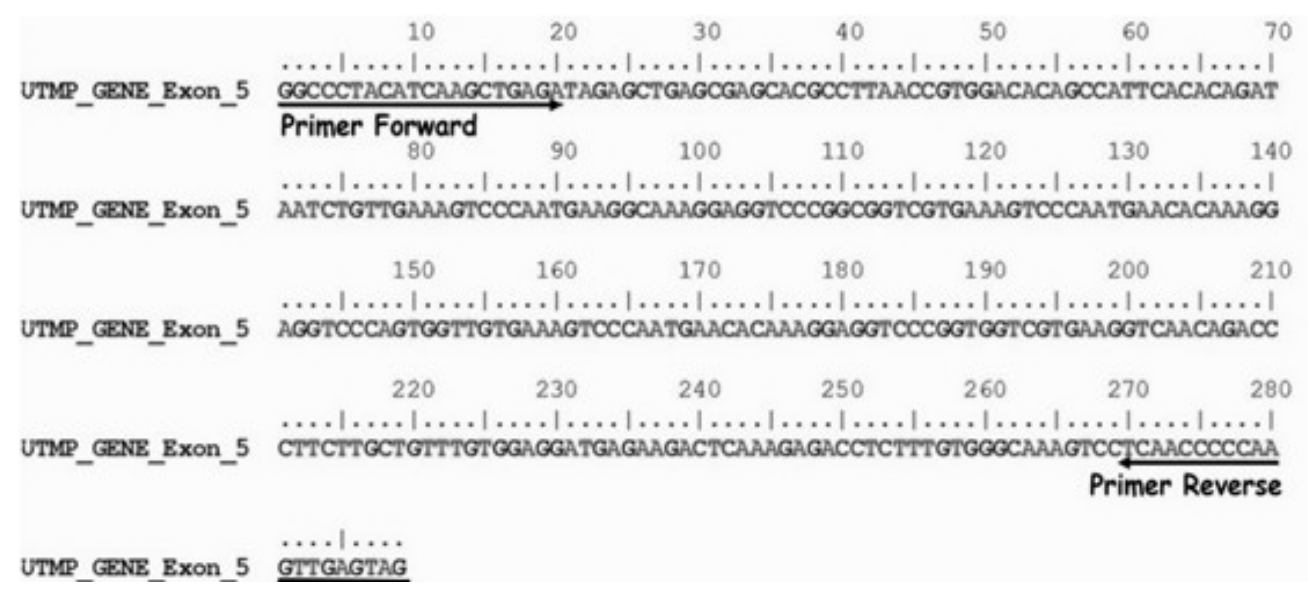

Figure 1. Amplification Primer (underline) in the Sequence of the Exon 5 UTMP Gene Fragment (GenBank access number L22095).

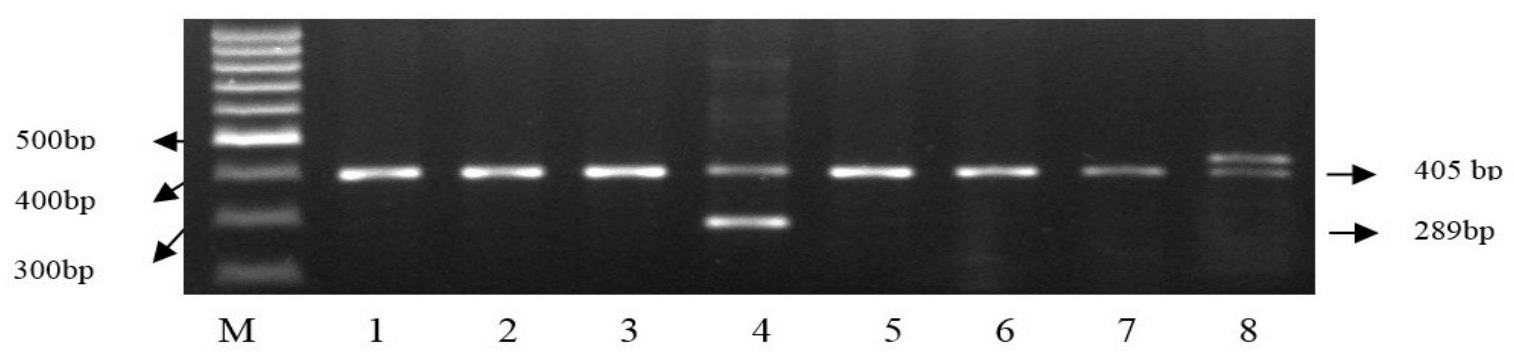

Figure 2. PCR Product Electrophoresis of Exon 5 UTMP Gene in Bali Cattle. M is marker of $100 \mathrm{bp}$, line 1-8 is sample of Bali cattle

an insertion mutations in Bali cattle PCR product. $\mathrm{Li}$ and Graur (1991) stated that the insertion is one type of mutation that increases one or more nucleotide in DNA sequence.

\section{Nucleotide Diversity of Exon 5 UTMP Gene}

Haplotype analysis identified 16 haplotypes in the exon 5 UTMP gene fragment from Bali cattle. They were distributed in BPTU Bali cattle in Bali Island (5 haplotypes), BPTU Bali cattle in Serading-Sumbawa NTB (5 haplotypes) and VBC Barru South Sulawesi (8 haplotypes) as presented in Figure 3. A total 16 haplotypes containing around 50 single nucleotide polymorphisms (SNPs) found in three Bali cattle populations may be used as a potential new candidates marker for reproductive traits in cattle Bali (Figure 3). The number of haplotypes $(\mathrm{H})$, haplotype diversity $(\mathrm{h})$ and nucleotide diversity $(\pi)$ of Bali cattle are presented in Table 1.

The highest number of haplotypes was found in the Bali cattle population from VBC Barru South Sulawesi. Similarly, the highest value of the haplotype (h) and nucleotide $(\pi)$ diversities were detected in Bali cattle population in South Sulawesi VBC Barru, they were 0795 and 0016, respectively. Haplotype and nucleotide diversity of exon 5 UTMP gene which were found in Bali cattle population is very important. GoodallCopestake et al., (2012) stated that the genetic diversity is an important as a reference for the conservation and management programs.

Minisatellite motive insertions in exon 5 UTMP gene fragment with sequence nucleotide 5'- CCA GTC ATG AAG AAG GCA GAG GTC GTC GTG CCG GCG AAA -3 'was found from 
Table 1. Exon 5 UTMP Gene Diversity in Three Populations of Bali Cattle

\begin{tabular}{lcccc}
\hline \multicolumn{1}{c}{ Bali Cattle Population } & $\mathrm{n}$ & $H$ & $h$ & $\pi$ \\
\hline VBC Barru district South Sulawesi & 20 & 8 & 0.795 & 0.016 \\
BPTU in Bali island & 20 & 5 & 0.585 & 0.005 \\
BPTU in Sumbawa NTB & 20 & 5 & 0.708 & 0.010 \\
\hline
\end{tabular}

n: individual number, $H$ : number of haplotype, $h$ : haplotype diversity, $\pi$ : nucleotide diversity

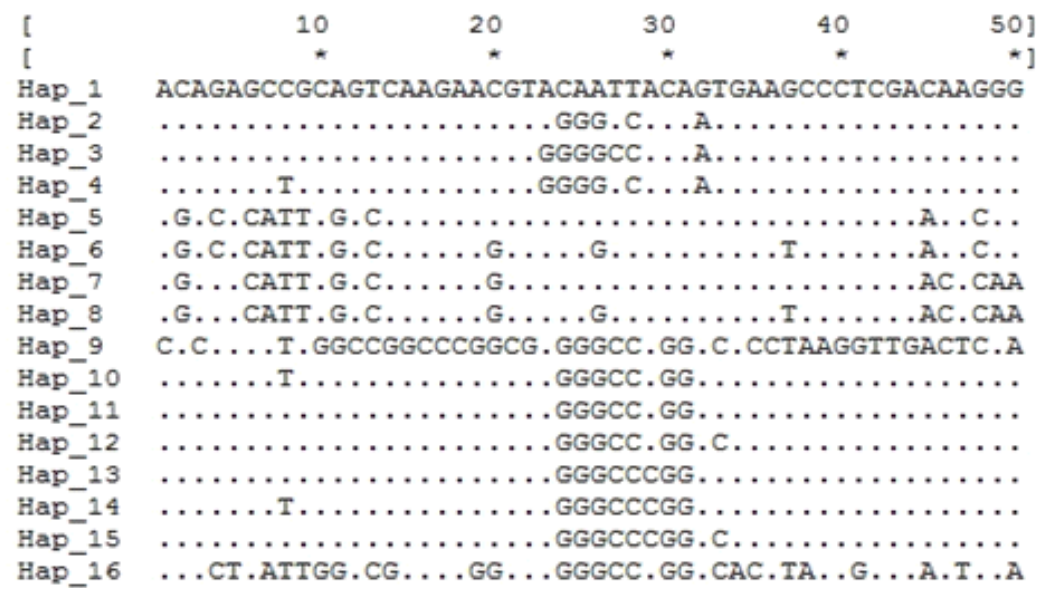

Figure 3. The Haplotype Diversity of Exon 5 UTMP Gene Fragment in Bali Cattle

sequencing analysis (Figure 4). Pathak et al., (2010) reported that the classification of minisatellites were 10 up to $100 \mathrm{bp}$ on the number of nucleotide sequences. It is clear that the length of PCR products difference between the this study $(405 \mathrm{bp})$ the one of fragment reference $(289 \mathrm{bp})$ were come from variations of minisatellite in exon 5 UTMP gene. Insertion minisatellite in exon 5 UTMP genes may influence the expression of the produced protein and the possible effect on the gene function. Amino acid sequences generating minisatellite insertion are VPMKAKEVPAVVK. The uniqueness of minisatellite insertion sequences in the exon 5 UTMP gene fragment was only found in Bali cattle population and it was not found in GenBank reference sequences such as reference sequences in UTMPBT201006 Simmental, BT301003 Limousin and L22095 access numbers. The diversity of minisatellite marker could be used as a genetic marker in the study of functional and comparative genomics analysis (Pathak et al., 2010).

Genetic diversity of exon 5 UTMP gene utilization has been reported by Khatib et al., (2007), namely mutation c1.779A $>\mathrm{G}$ and c1.296A $>\mathrm{G}$ associated with the increase of the lifetime of productive $\mathrm{FH}$ cattle. In addition, the GG genotype has lower embryos survival than GA and AA genotypes. Kandasamy et al., (2010) stated that gene expression UTMP was controlled by progesterone synthesis and predominantly found in the endometrium playing a role in maintaining pregnancy. UTMP gene expression also plays as important factor in the productive living age of dairy cattle (Khatib et al., 2009). Genetic diversity particularly haplotype diversity and minisatellite obtained in exon 5 UTMP gene in Bali cattle can be used as a marker for reproduction marker candidate. However, it is 
needed to investigate the association between haplotype and reproductive trait. Therefore, the haplotype diversity and minisatellite can be used as a reference in the Bali cattle breeding program strategy in the future.

\section{CONCLUSION}

Analysis of genetic diversity of exon 5 UTMP gene on Bali cattle found 16 haplotypes and highest haplotype and nucleotide diversity were detected in VBC Barru district South Sulawesi. This study also identified minisatellite motive sequences in exon 5 UTMP gene of Bali cattle. Genetic diversity in exon 5 UTMP gene fragment can be used as a candidate genetic marker specific in the Bali cattle and for breeding program strategy in the future.

\section{ACKNOWLEDGMENT}

Authors thank to Ministry of Research and Technology for the financial support of the National Synergy Incentive Research (InSinas) with the contract number 25/SEK/INSINAS/PPK/I/2014 and 12/SEK/ INSINAS/PPK/IV/2015.

\section{REFERENCES}

Entwistle, K. and D.R. Lindsay. 2003 Strategies to improve Bali cattle in Eastern Indonesia. Proceedings, Bali Indonesia Feb. 4-7, 2002. P100:1-2.

Goodall-Copestake, W.P., G.A. Tarling and E.J. Murphy. 2012. On the comparison of population-level estimates ofhaplotype and nucleotide diversity: a case study usingthe gene cox1 in animals. Heredity. 109: 50-56.

Hall, T.A. 1999. BioEdit: a user-friendly biological sequence alignment editor and analysis program for Windows 95/98/NT. Nucl.Acids.Symp. Ser. 41:95-98.

Jakaria and R. R. Noor. 2011. Analysis on Alu-I growth hormone (GHAlu-I) gene in Bali cattle. J. Indonesian Trop. Anim Agric. 36(2):77-82.

Jakaria and R. R. Noor. 2015. Identification of a single nucleotide polymorphism at Hinf-1 enzyme restriction site of Pit-1 gene on Indonesian Bali cattle population. Med. Pet. 38(2):104-109.

Kandasamy, S., A. Jain, R. Kumar, S. K. Agarwal, P. Joshi and A. Mitra. 2010. Molecular characterization and expression profile of uterine serpin (SERPINA14) during different reproductive phases in water buffalo (Bubalus bubalis). Anim. Reprod. Sci. 122:133-141.

Khatib, H., W. Huang, X. Wang, A.H. Train, A.B. Bindrim, V. Schutzkus and R.L. Monson. 2009. Single gene and gene interaction effects on fertilization and embryonic survival rates in cattle. J. Dairy Sci. 92: 2238-2247.

Khatib, H., V. Schutzkuz, Y.M. Changand G.J.M. Rosa. 2007. Pattern of expression of uterine milk protein gene and its association with productive life in dairy cattle. J. Dairy Sci.90: 2427-2433.

Koichiro, T., D. Peterson, N. Peterson, G.Stecher, M. Nei, and S.Kumar. 2011. MEGA5: Molecular Evolutionary Genetics Analysis Using Maximum Likelihood, Evolutionary Distance, and Maximum Parsimony Method. Molec Biol and Evo 28: 27312739.

Li, W.H and D. Graur.1991. Fundamentals of Molecular Evolution. Sinauer Associates Inc. Publisher. Sunderland, Massachusetts.

Librado, P. and J. Rozas. 2009. DnaSP v5: A software for comprehensive analysis of DNA polymorphism data. Bioinformatics 25:1451-1452.

McCool, C. 1992.Buffalo and Bali cattle-their reproductive behaviour and physiology. J. Tropic. Anim. Health and Prod. 24:165.

Padua, M.B. and P.J. Hansen. 2010. Evolution and function of the uterine serpins (SERPINA14). Am. J. Reprod. Immun. 64(4):265-274.

Paramitasari, K. A., C. Sumantri and Jakaria. 2015. The Genetic variability of prolactin and signal transducers and activators of transcription 5A (STAT5A) genes in Bali cattle. Med.Pet. 38(1):1-11.

Pathak, D., J. Srivastava, R. Samad, I. Parwez, S. Kumar and S. Ali. 2010. Genome-wide search of the genes tagged with the consensus of 33.6 repeat loci in buffalo Bubalus bubalis employing minisatelliteassociated sequence amplification. Chrom. Res. 18:441-458.

Purwantara, B., R.R. Noor, G. Andersson and H. Rodriguez-Martinez. 2012. Banteng and Bali Cattle in Indonesia: Status and Forecasts. J. Reprod. Domes. Anim. 47:2-6.

Putri, R., R. Priyanto, A. Gunawan and Jakaria. 
2015. Association of calpastatin (CAST) gene with growth traits and carcass characteristics in Bali cattle. Med. Pet. 38(3):145-149.

Pribadi L.W., S. Maylinda, M. Nasich and S. Suyadi. 2015.Reproductive efficiency of Bali cattle and it's crosses with Simmental breed in the lowland and highland areas of West Nusa Tenggara Province, Indonesia.Liv. Res. for Rur.Dev. 27 (2): online edition.
Ulbrich, S.E., F. Thomas, S. Katy, E. Eva, W. Nadine, J.A. George, R. Horst, R. Myriam, W. EckhardandM. Heinrich. 2009. Evidence for Estrus-Dependent Uterine Serpine (SERPINA 14) expression during estrus in the bovine endometrial glandular epithelium and lumen. J Biol. Reprod. 81:795-805.

Zulkharmaim, Jakaria and R. R. Noor. 2010. Identifikasi keragaman gen hormon pertumbuhan reseptor lokus Alu-1 pada sapi Bali. Med. Pet.. 33(2):45-51. 